\title{
An investigation on the effects of perception and marketing expenditure, financial and non- financial promotions on brand equity
}

\author{
Abbas Ataheryan ${ }^{a^{*}}$, Masoumeh Sadat Abtahi ${ }^{\mathrm{b}}$ and Ahmad Rahchamani ${ }^{\mathrm{a}}$
}

${ }^{a}$ Department of strategic Management, Qazvin Branch, Islamic Azad University, Qazvin, Iran

${ }^{b}$ Department of Humanities, Zanjan Branch, Islamic Azad University, Zanjan, Iran

\begin{tabular}{|c|c|}
\hline CHRON I C L E & ABSTRACT \\
\hline $\begin{array}{l}\text { Article history: } \\
\text { Received May 15, } 2013 \\
\text { Received in revised format } \\
17 \text { August } 2013 \\
\text { Accepted } 18 \text { August } 2013 \\
\text { Available online } \\
\text { August } 212013 \\
\text { Keywords: } \\
\text { Brand equity } \\
\text { Perception quality } \\
\text { Financial promotion }\end{array}$ & $\begin{array}{l}\text { This paper presents a study to investigate the effects of perception and marketing expenditures } \\
\text { as well as financial and non-financial promotions on brand equity. The proposed study of this } \\
\text { paper prepares a questionnaire in Likert scale and distributes it among regular customers of } \\
\text { three types of Shampoo in city of Tehran, Iran. The implementation of structural equation } \\
\text { modeling for the proposed study of this paper has been accomplished based on LISREL } \\
\text { software. The results of the survey on testing various hypotheses indicate that perception on } \\
\text { marketing expenditure, financial as well as non-financial promotion and word of mouth } \\
\text { advertisement influence positively on brand awareness and negatively on non-financial } \\
\text { promotions }(\alpha=0.01) \text {. In addition, brand awareness influences positively on perception quality } \\
(\alpha=0.01) \text {. Brand awareness as well as brand associate also influence on brand loyalty }(\alpha=0.01) \text {. }\end{array}$ \\
\hline
\end{tabular}

\section{Introduction}

Marketing planning is one of the most important actions accomplished to penetrate into market (Christodoulides \& De Chernatony, 2010). It plays essential role on improving market share and absorbing more customers as well as having better customer retention (Ajzen \& Fishbein 1980; Campbell \& Diamond, 1990; Davis \& Dunn, 2002; Aaker, 2009). Building global brand is the most important components of marketing planning and big corporations normally plan to have diversified products in various countries (Cobb-Walgren et al., 1995; Batra, 2009). Brand equity is one of the most components of marketing planning and there are literally various attempts to detect different factors influencing marketing planning (Agarwal \& Rao, 1996; Chu \& Keh, 2006). 
Ataman et al. (2010) stated that only few studies had considered the relative impact of the integrated marketing mix including advertising, price promotion, product, and place on the long-term performance of mature brands, instead concentrating on advertising and price promotion. Therefore, little guidance exists to firms on the relative efficacy of their different marketing expenses over the long run. To study this issue, the Ataman et al. (2010) applied a multivariate dynamic linear transfer function model on 70 brands in France and reported that the total short-term plus long-term sales elasticity was 1.37 for product and .74 for distribution. They further reported that the long-term impacts of discounting were one-third the magnitude of the short-term impacts. The ratio was reversed from other aspects of the mix where long-term impacts exceeded four times the short-term effects, implying the strategic effect of these tools in brand sales.

Ashill and Sinha (2004) performed an exploratory investigation into the effect of components of brand equity and country of origin effects on purchase intention. Atilgan et al. (2005) studied the practicality and application of a customer-based brand equity model, based on Aaker's well-known conceptual framework (Aaker, 2009) of brand equity. They concluded that brand loyalty was the most influential dimension of brand equity but reported weak support for the brand awareness and perceived quality dimensions.

Bharadwaj et al. (1993) tried to reach a sustainable competitive advantage (SCA) and thereby enhance a business's performance. They concentrated on the distinctive organizational skills and resources underlying SCA in service industries and the moderating impacts of the characteristics of services, service industries, and firms within an industry on the skills and resources underlying a business's competitive positional advantages. Gil et al. (2007) analyzed the effects of the family on consumer-based brand equity in a model where information of a brand provided by both the family and the firm was investigated as a source of consumer-based brand equity and its dimensions. They reported that positive brand information provided by the family could influence on the formation of brand awareness-associations and perceived quality, and this could lead in turn, to brand loyalty and overall brand equity.

Buil et al. (2013) explored the relationships between two central elements of marketing communication programs including the advertising and the sales promotions. They also investigated the effects of these two components on brand equity creation. More specifically, the research concentrated on advertising spend and individuals' attitudes toward the advertisements. They also investigated the impacts of two kinds of sales promotions, monetary and non-monetary promotions. They reported that the individuals' attitudes toward the advertisements played essential role on influencing brand equity dimensions, whereas advertising spent on brands under investigation could improve brand awareness but it was insufficient to positively impact brand associations and perceived quality. They reported distinctive impacts of monetary and non-monetary promotions on brand equity. Besides, the results indicated that firms could optimize the brand equity management process by considering the relationships existing between the various dimensions of brand equity (Feldwick, 1996).

Baldauf et al. (2003) stated that assessing the consequences of brand equity management is one of the most essential measurement factors for intangible assets in the new economy. Chaudhuri and Holbrook (2001) investigated the chain of factors from brand trust and brand influencing on brand performance by studying the role of brand loyalty. According to Doyle (2001) companies like Procter \& Gamble, Unilever, Xerox, Heinz, Apple and Gillette possess excellent brands and good brand management competencies, yet they have failed to create value for shareholders for many years. What these companies were learning was that having strong brands which consumers value was not sufficient. Whether strong brands generate value for shareholders depends on the economics of the markets in which they operate and the strategies managers pursue. 


\section{The proposed study}

This paper presents a study to investigate the effects of perception and marketing expenditures as well as financial and non-financial promotions on brand equity. The proposed study of this paper prepares a questionnaire in Likert scale and distributes it among regular customers of three types of Shampoo in city of Tehran, Iran. The implementation of structural equation modeling for the proposed study of this paper has been accomplished based on LISREL software (See Fig. 1). The proposed study considers the following hypotheses,

1. Consumer's perception on marketing expenditures influences on quality perception.

2. Consumer's perception on marketing expenditures influences on brand awareness.

3. Consumer's perception on marketing expenditures influences on brand associate.

4. Consumer's attitude on marketing expenditures influences on quality perception.

5. Consumer's attitude on marketing expenditures influences on brand awareness.

6. Consumer's attitude on marketing expenditures influences on brand associate.

7. Consumer's perception on financial promotions influences on quality perception.

8. Consumer's perception on financial promotions influences on brand associate.

9. Consumer's perception on non-financial promotions influences on quality perception.

10. Consumer's perception on non-financial promotions influences on brand associate.

11. Consumer's brand awareness has relationship with perception quality.

12. Consumer's brand awareness has meaningful relationship with brand awareness.

13. Consumer's quality perception has meaningful relationship with brand loyalty.

14. Consumer's brand associate has meaningful relationship with brand loyalty.

15. Consumer's word of mouth has meaningful relationship with quality perception.

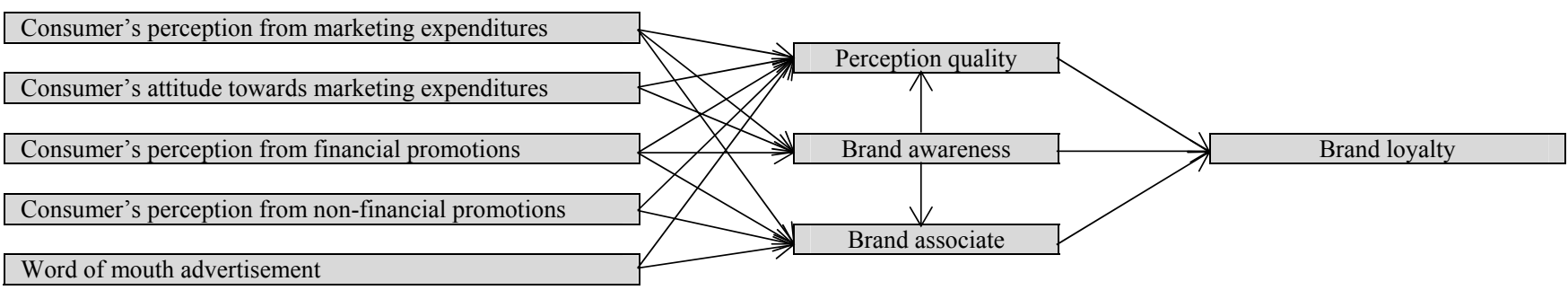

Fig. 1. The proposed study (Ref: Buil et al., 2013)

The population of this survey includes all 6 million potential customers who purchase three brands of shampoo. Therefore, the sample size is calculated as follows,

$n=\frac{N \times z_{\alpha / 2}^{2} \times p \times q}{\varepsilon^{2} \times(N-1)+z_{\alpha / 2}^{2} \times p \times q}$,

where $N$ is the population size, $p=1-q$ represents the yes/no categories, $z_{\alpha / 2}$ is CDF of normal distribution and finally $\varepsilon$ is the error term. Since we have $p=0.5, z_{\alpha / 2}=1.96$ and $N=6,000,000$, the number of sample size is calculated as $n=268$. Table 1 demonstrates the summary of average variance estimation (AVE) as well as Cronbach ratios. 


\section{Table 1}

The summary of Cronbach alpha

\begin{tabular}{lcc}
\hline Variable & AVE & CR \\
\hline Consumer's perception from marketing expenditures & 0.79 & 0.75 \\
Consumer's attitude towards marketing expenditures & 0.74 & 0.69 \\
Financial promotions & 0.83 & 0.74 \\
Non-financial promotions & 0.81 & 0.76 \\
Word of mouth & 0.77 & 0.82 \\
Quality perception & 0.85 & 0.88 \\
Brand awareness & 0.73 & 0.77 \\
Brand associate & 0.73 & 0.68 \\
Brand loyalty & 0.75 & 0.71 \\
\hline
\end{tabular}

As we can observe from the results of Table 1, all statistical observations are within acceptable limits and we can observe the linear regression model.

\subsection{Regression analysis}

In this section, we first present details of regression analysis on measuring the effects of various variables on perception quality, brand awareness, etc.

\subsubsection{The effects of different components on perception quality}

Table 2 demonstrates the effects of consumer's perception from marketing expenditures, consumer's attitude towards marketing expenditures, financial promotions, non-financial promotions and word of mouth on perception quality as follows,

Table 2

The results of the effects independent variables with perception quality as dependent variable

\begin{tabular}{lcc}
\hline Variable & $\beta$ & t-value \\
\hline Consumer's perception from marketing expenditures & -0.19 & $-3.77^{* *}$ \\
Consumer's attitude towards marketing expenditures & 0.52 & $3.49^{* *}$ \\
Financial promotions & -0.25 & $-4.07^{* *}$ \\
Non-financial promotions & 0.51 & $3.24^{* *}$ \\
Word of mouth & 0.48 & $2.12^{*}$ \\
\hline$* \mathrm{P}<0.05 * \mathrm{P}<0.01 \mathrm{R}^{2}=0.61$ & &
\end{tabular}

As we can observe from the results of Table 2, most components are meaningful when the level of significance is five or one percent. There are two negative and three positive effects from independent variables on perception quality.

\subsubsection{The effects of different variables on brand awareness}

Similarly, Table 3 investigates the effects of consumer's perception from marketing expenditures, consumer's attitude towards marketing expenditures, and word of mouth on brand awareness as follows,

\section{Table 3}

The results of the effects independent variables with brand awareness as dependent variable

\begin{tabular}{lcc}
\hline Variable & $\beta$ & t-value \\
\hline Consumer's perception from marketing expenditures & 0.52 & $3.04^{* *}$ \\
Consumer's attitude towards marketing expenditures & 0.47 & $2.44^{*}$ \\
Word of mouth & 0.53 & $2.14^{* *}$ \\
\hline
\end{tabular}

\footnotetext{
$* \mathrm{P}<0.05 * * \mathrm{P}<0.01 \mathrm{R}^{2}=0.77$
} 


\subsubsection{The effects of different variables on brand associate}

The other investigation is to see the effects of different variables on brand associate. Table 4 demonstrates the effects of consumer's perception from marketing expenditures, consumer's attitude towards marketing expenditures, financial promotions, non-financial promotions and word of mouth on brand associate as follows,

\section{Table 4}

The results of the effects independent variables with brand associate as dependent variable

\begin{tabular}{lcc}
\hline Variable & $\beta$ & $\mathrm{t}$-value \\
\hline Consumer's perception from marketing expenditures & 0.56 & $3.16^{* *}$ \\
Consumer's attitude towards marketing expenditures & 0.61 & $3.50^{* * *}$ \\
Financial promotions & -0.12 & $-1.31^{* *}$ \\
Non-financial promotions & 0.50 & $4.11^{* *}$ \\
Word of mouth & 0.54 & $2.92^{* *}$ \\
\hline${ }^{*} \mathrm{P}<0.0{ }^{* *} \mathrm{P}<0.01 \mathrm{R}^{2}=0.48$ & &
\end{tabular}

$* \mathrm{P}<0.05 * * \mathrm{P}<0.01 \mathrm{R}^{2}=0.48$

As we can observe from the results of Table 4, most components are meaningful when the level of significance is one percent. The effects of four variables are positive on brand associate and only financial promotion maintains a negative influence on brand associate.

\subsubsection{The effects of different variables on perception quality}

Similarly, Table 5 investigates the effects of consumer's perception from marketing expenditures, consumer's attitude towards marketing expenditures, and word of mouth on perception quality as follows,

\section{Table 5}

The results of the effects independent variables with perception quality as dependent variable

\begin{tabular}{lcc}
\hline Variable & $\beta$ & $\mathrm{t}$-value \\
\hline Brand awareness & 0.65 & $3.62^{* *}$
\end{tabular}

The result of Table 5 clearly specifies that brand awareness influences positively on perception quality when the level of significance is one percent.

\subsubsection{The effects of different variables on brand associate}

Similarly, Table 5 investigates the effects of consumer's perception from marketing expenditures, consumer's attitude towards marketing expenditures, and word of mouth on brand associate as follows,

\section{Table 5}

The results of the effects independent variables with brand associate as dependent variable

\begin{tabular}{lcc}
\hline Variable & $\beta$ & $\mathrm{t}$-value \\
\hline Brand awareness & 0.54 & $3.51^{* *}$ \\
\hline$* \mathrm{P}<0.05 * \mathrm{P}<0.01 \mathrm{R}^{2}=0.74$ & &
\end{tabular}

The result of Table 5 clearly specifies that brand awareness influences positively on brand associate when the level of significance is one percent.

\subsubsection{The effects of different variables on brand loyalty}

Similarly, Table 6 investigates the effects of consumer's perception from marketing expenditures, consumer's attitude towards marketing expenditures, and word of mouth on brand loyalty as follows, 


\section{Table 6}

The results of the effects independent variables with brand loyalty as dependent variable

\begin{tabular}{lcc}
\hline Variable & $\beta$ & $\mathrm{t}$-value \\
\hline Quality perception & 0.67 & $3.35^{* *}$ \\
Brand associate & 0.63 & $3.46^{* *}$ \\
\hline
\end{tabular}

$* \mathrm{P}<0.05 * * \mathrm{P}<0.01 \mathrm{R}^{2}=0.72$

The result of Table 6 clearly specifies that quality perception and brand associate influence positively on brand loyalty when the level of significance is one percent.

\subsection{The conceptual model}

In this section, we present details of the implementation of structural equation model on the proposed study of this paper. Table 7 summarizes details of statistical observations on testing various components. The results of Table 7 also imply that the outputs of LISREL method are trustable.

\section{Table 7}

The summary of statistical observations

\begin{tabular}{lcc}
\hline Attribute & Value & Desirable value \\
\hline Chi-square/df & 2.13 & $<3$ \\
GFI & 0.91 & $>0.9$ \\
RMSEA & 0.074 & $<0.1$ \\
CFI & 0.95 & $>0.9$ \\
AGFI & 0.84 & $>0.80$ \\
NFI & 0.92 & $>0.90$ \\
NNFI & 0.94 & $>0.90$ \\
\hline
\end{tabular}

NFI: Normed Fit Index NNFI: Non Normed Fit Index CFI: Comparative Fit Index GFI: Goodness of Fit Index

AGFI: Adjustment Goodness of Fit Index RMSEA: Root Mean Square Error of Approximation



Fig. 2. The result of structural equation model 


\section{Discussion and conclusion}

In this paper, we have presented the effects of perception and marketing expenditures as well as financial and non-financial promotions on brand equity. The proposed study used regression analysis as well as structural equation modeling to investigate the effects of various factors. The results of regression analysis of consumer's perception from marketing expenditures, consumer's attitude towards marketing expenditures, financial promotions, non-financial promotions and word of mouth as independent variable on perception quality has indicated that there was some meaningful relationship between independent variables and perception quality. We have also determined that consumer's perception from marketing expenditures, consumer's attitude towards marketing expenditures, and word of mouth on brand awareness influence on brand awareness. The study also used regression analysis to demonstrate the effects of consumer's perception from marketing expenditures, consumer's attitude towards marketing expenditures, financial promotions, nonfinancial promotions and word of mouth on brand associate and the results have indicated some meaningful relationship between independent variables and dependent variable. The survey also indicated that there was a meaningful relationship between brand awareness and perception quality and between brand awareness and brand associate. Finally, the results of regression analysis clearly specified that quality perception and brand associate could influence positively on brand loyalty when the level of significance is one percent.

The implementation of structural equation modeling for the proposed study of this paper has been accomplished based on LISREL software. The results of the implementation of structural equation modeling on testing various hypotheses have indicated that perception to marketing expenditure, financial as well as non-financial promotion and word of mouth advertisement influence positively on brand awareness and negatively on non-financial promotions $(\alpha=0.01)$. In addition, brand awareness influenced positively on perception quality $(\alpha=0.01)$. Brand awareness as well as brand associate also influence on brand loyalty $(\alpha=0.01)$.

\section{References}

Aaker, D. A., \& Joachimsthaler, E. (1999). The lure of global branding. Harvard Business Review, 77, 137-146.

Aaker, D. A. (2009). Managing brand equity. SimonandSchuster. com.

Agarwal, M. K., \& Rao, V. R. (1996). An empirical comparison of consumer-based measures of brand equity. Marketing Letters, 7(3), 237-247.

Ajzen I, \& Fishbein M. (1980). Understanding attitudes and predicting social behavior. Englewood Cliffs, NJ: Prentice Hall.

Ashill, N. J., \& Sinha, A. (2004). An exploratory study into the impact of components of brand equity and country of origin effects on purchase intention. Journal of Asia-Pacific Business, 5(3), 27-43.

Ataman, M. B., Van Heerde, H. J., \& Mela, C. F. (2010). The long-term effect of marketing strategy on brand sales. Journal of Marketing Research, 47(5), 866-882.

Atilgan, E., Aksoy, S., \& Akinci, S. (2005). Determinants of the brand equity: a verification approach in the beverage industry in Turkey. Marketing intelligence \& planning, 23(3), 237-248.

Batra, R. (2009). Advertising Management, 5/e. Pearson Education India.

Baldauf, A., Cravens, K. S., \& Binder, G. (2003). Performance consequences of brand equity management: evidence from organizations in the value chain. Journal of product \& brand management, 12(4), 220-236.

Bharadwaj, S. G., Varadarajan, P. R., \& Fahy, J. (1993). Sustainable competitive advantage in service industries: a conceptual model and research propositions. The Journal of Marketing, 57(4), 83-99.

Buil, I., de Chernatony, L., \& Martínez, E. (2013). Examining the role of advertising and sales promotions in brand equity creation. Journal of Business Research, 66(1), 115-122. 
Campbell, L., \& Diamond, W. D. (1990). Framing and sales promotions: The characteristics of a good deal?. Journal of Consumer Marketing, 7(4), 25-31.

Chaudhuri, A., \& Holbrook, M. B. (2001). The chain of effects from brand trust and brand affect to brand performance: the role of brand loyalty. The Journal of Marketing, 81-93.

Christodoulides, G., \& De Chernatony, L. (2010). Consumer-based brand equity conceptualization and measurement: A literature review. International Journal of Research in Marketing, 52(1), 4366.

Chu, S., \& Keh, H. T. (2006). Brand value creation: Analysis of the Interbrand-Business Week brand value rankings. Marketing Letters, 17(4), 323-331.

Gil, R. B., Andrés, E. F., \& Salinas, E. M. (2007). Family as a source of consumer-based brand equity. Journal of Product \& Brand Management, 16(3), 188-199.

Cobb-Walgren, C. J., Ruble, C. A., \& Donthu, N. (1995). Brand equity, brand preference, and purchase intent. Journal of Advertising, 24(3), 25-40.

Davis, S. M., \& Dunn, M. (2002). Building the brand-driven business: Operationalize your brand to drive profitable growth. San Francisco, CA: Jossey-Bass.

Doyle, P. (2001). Shareholder-value-based brand strategies. The Journal of Brand Management, 9(1), 20-30.

Feldwick, P. (1996). Do we really need' brand equity'?. Journal of Brand Management, 4, 9-28. 